\title{
More Holistic Thinking and Broader Accounting Stances for Energy, Food and Environment
}

ISSN: 2637-7659

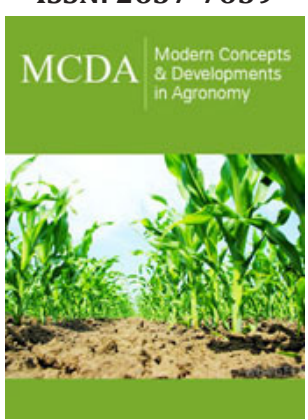

*Corresponding author: Fred Hitzhusen, Professor Emeritus, AEDE, Columbus, Ohio

Submission: 監July 01, 2020

Published: 疅July 08, 2020

Volume 6 - Issue 5

How to cite this article: Fred Hitzhusen. More Holistic Thinking and Broader Accounting Stances for Energy, Food and Environment. Mod Concep Dev Agrono. 6(5). MCDA. 000647. 2020. DOI: 10.31031/MCDA.2020.06.000647

Copyright@ Fred Hitzhusen, This article is distributed under the terms of the Creative Commons Attribution 4.0 International License, which permits unrestricted use and redistribution provided that the original author and source are credited.

\section{Fred Hitzhusen*}

Professor Emeritus, AEDE, Columbus, Ohio

\section{Letter to Editor}

I am responding to several recent Dispatch editorial/letters to the editor on the costs and benefits of fracking for shale gas development, livestock stock waste/phosphorous run off pollution of Ohio lakes and the use of gypsum sludge from coal power plant scrubbers to bind with and hold the phosphate in the soil (Dr. Dick, OARDC, OSU). By adding an additional issue it is possible to show a holistic convergence of all four issues. The fourth issue is the increased cost of coal electric generation when downstream surface mining and downwind acid rain and greenhouse gas economic costs are included in the price of coal-based electricity, i.e., broadening the accounting stance. Recent research at Ohio State University published in the Journal of Environmental Management [Vol.100 (2012) pp. 52-58] shed some light on the economic costs from abandoned surface mine impacts on downstream lake recreation. When the four foregoing issues are viewed as an interrelated set of issues, new principles and options for wise and sustainable environmental and economic development policy emerge.

The first principle is that the full costs including subsidies and environmental impacts of all renewable and nonrenewable energy options need to be incorporated in any comparisons of options. The second principle is to look for a win win solution whenever possible. For example, current livestock manure field applications contribute to the phosphorous runoff resulting in Ohio lake algal blooms. However, it is possible to utilize anaerobic digestion of the farm waste to produce a renewable methane/biogas, and to provide for more precise application of resulting liquid fertilizer. As a result, major reductions in pollution of downstream water bodies and reduced odor impacts on home values (see OSU PhD dissertation research by Dabrowska) are possible. In addition, a useful and more benign compost material results from the anaerobic digestion process and for excess phosphates already in the soil, the application of the gypsum dried sludge can reduce their runoff. Farmers gain a new revenue source, downstream homeowners and lake users gain increased property values and recreation benefits and society gains a renewable biofuel for the electric power grid. Some have argued that biogas from waste as well as other renewables are not "economically" feasible but they do so utilizing a very narrow accounting stance. Imagine the possibility of reducing a serious lake algal bloom problem, having a new renewable biofuel for on-farm power and the electric power grid and recycling one of the waste streams from coal-based electric generation. In addition, it could allow slowing the pace of shale gas development until the full environmental, public health and safety consequences of fracking are better understood and more appropriate severance taxes applied.

For possible submissions Click below:

Submit Article 